\title{
Paradoxically Psoriasis, developed in a patient using adalimumab for ankylosing spondylitis: Case report
}

\section{Ankillozan spondilitli hastada adalimumab tedavisine bağlı gelişen paradoksik psöriazis: Olgu sunumu}

\author{
Sena I̊rkinin', Neşe Çabuk Çeliik², Burak Karakaş², Beliz Karataş², Ali Şahin²
}

Cumhuriyet Univercity Medical Faculty, Sivas, Turkey

${ }^{2}$ Cumhuriyet Univercity Medical Faculty Deparmant of Internal Medicine/Rheumatology, Sivas, Turkey

Corresponding author: Neșe Cabuk Çelik, MD, Cumhuriyet Univercity Medical Faculty Deparmant of Internal Medicine/Rheumatology, Sivas, Turkey

E-mail: nesecabuk@gmail.com

Received/Accepted: December 18, 2020 / June 30, 2021

Conflict of interest: There is not a conflict of interest.

\begin{abstract}
SUMMARY
Anti-tumor necrosis factor agents are effective drugs for inflammatory diseases such as rheumatoid arthritis and inflammatory bowel disease. Although it is indicated for the treatment of Ankylosing Spondylitis, there are recent publications about paradoxical side effects due to these agents, mostly in the form of case reports. In this article, we present the psoriasis case that develops paradoxically in a patient with ankylosing spondylitis using adalimumab.
\end{abstract}

Keywords: Adalimumab, ankylosing spondylitis, paradoxal psoriasis

\author{
(D) Sena İrkin \\ (iD) Neşe Çabuk Çelik \\ (iD Burak Karakaş \\ (iD) Beliz Karataş \\ iD Ali Şahin
}

ORCID IDs of the authors: S.İ. 0000-0002-7840-2451 N.C.C. 0000-0002-9045-7105

B.K. 0000-0003-3624-4958

B.K. 0000-0002-4128-5845

A.Ş. 0000-0002-6953-4276

ÖZET

Anti-tümör nekroz faktör ajanları, romatoid artrit ve inflamatuar bağırsak hastalığı gibi inflamatuar hastalıklar için etkili ilaçlardır. Ankilozan Spondilit tedavisinde endike olmasına rağmen, bu ajanların neden olduğu paradoksal yan etkiler hakkında sıklıkla, olgu sunumu şeklinde güncel yayınlar bulunmaktadır. Bu makalede, ankilozan spondilit tanısı almış ve adalimumab kullanan bir hastada, paradoksal olarak gelişen psoriazis olgusunu sunuyoruz.

Anahtar sözcükler: Adalimumab, ankilozan spondilit, paradoksal psöriazis

\section{INTRODUCTION}

Tumor necrosis factor (TNF) is the name given to a group of cytokines involved in antitumor and immunoregulatory events. Its two known members are TNF- $\alpha$ and TNF- $\beta$. TNF- $\alpha$ is a major regulator of apoptosis ${ }^{1}$. AS, a common chronic inflammatory rheumatic disease, is the prototype and the most severe form of spondyloarthropathies. In spondylarthropathies, joint symptoms usually decrease with the use of non-steroidal antiinflammatory drugs (NSAIDs). However, in spondyloarthropathies refractory to NSAIDs and conventional DMARDs (Disease-modifying 
antirheumatic drugs), treatment with anti tumor necrosis factor (TNF) drugs is required. TNF- $\alpha$ blocker; etanercept, adalimumab, infiliksimab, golimumab, certolizumab are used in the treatment of these diseases. Dermatologic, intestinal, and ophthalmologic paradoxical side effects of these agents have been observed ${ }^{2}$. In this article, a case of paradoxical psoriasis diagnosed with psoriasiform eruptions after adalimumab treatment will be discussed.

\section{CASE REPORT}

A 33 years old male patient was admitted to our outpatient clinic with the complaints of rashes on the hands, knees, elbows, legs, groin and trunk, and nail changes for the last two months. It was learned that the patient was diagnosed with ankylosing

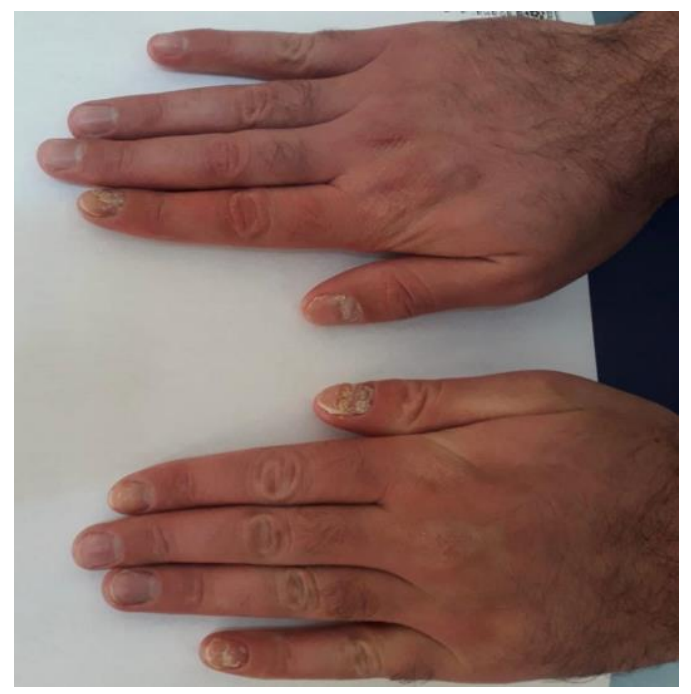

Figure 1: Bilateral palmoplantar region

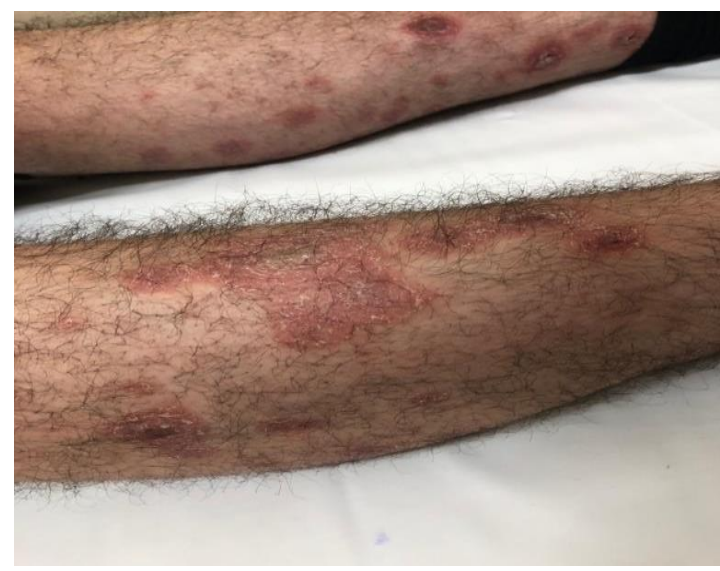

Figure 3: Psoriatic lesions on the anterior face of both tibia spondylitis for ten years and received $40 \mathrm{mg}$ adalimumab every two weeks. On physical examination, bilateral palmoplantar papullosquamous lesions (Figure 1) and onycholysis of the nail were observed (Figure 2). Also, there were psoriatic rashes on the front leg (Figure 3) and back (Figure 4). With all these findings, the patient was diagnosed with paradoxical psoriasis. Adalimumab which the patient used for AS treatment was discontinued. Sekukinumab treatment which is an IL-17 (interleukin-17) blocker was started. After two months, he benefited from the treatment, the rashes regressed significantly (Figure 5), but nail changes continued (Figure 6). In addition to being therapeutic for paradoxical psoriasis, sequkinumab treatment also enabled AS treatment to continue effectively ${ }^{3}$.

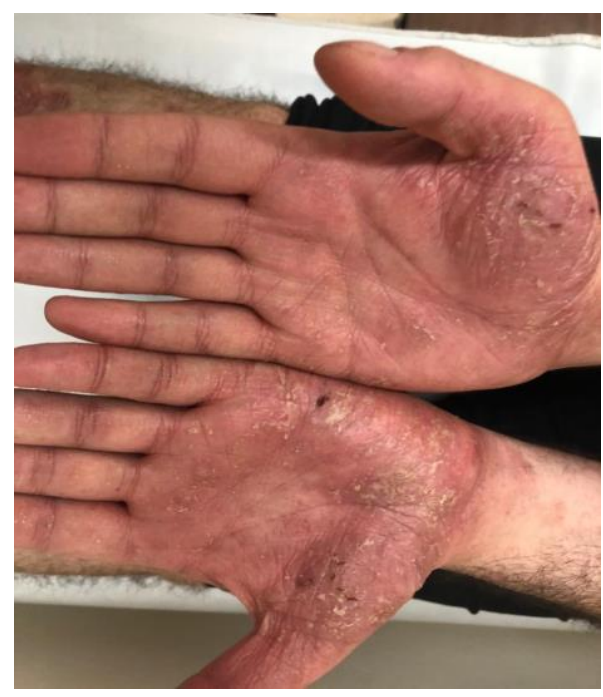

Figure 2: Onycholysis hyperkeratosis scattered pustules in the nail secondary to psoriasi

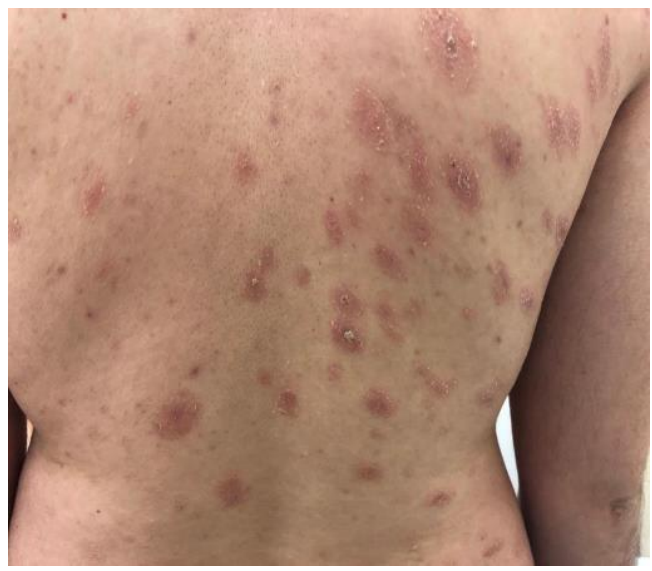

Figure 4: Psoriatic lesions on the back 


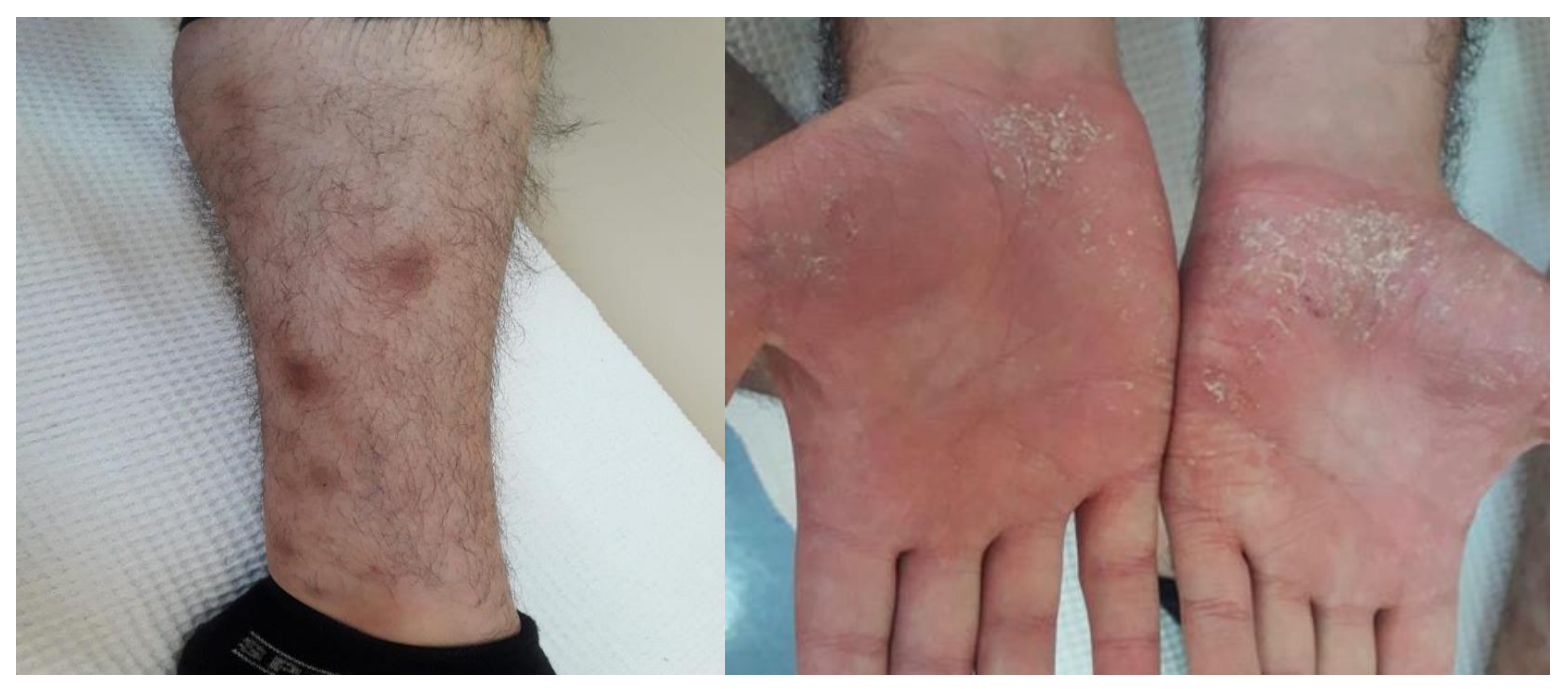

Figure 5: Lesions regressing after treatment

\section{DISCUSSION}

Anti-TNF agents; It has been shown to be highly effective in different inflammatory conditions such as RA, AS, Psoriatic Arthritis (PsA), Juvenile Idiopathic Arthritis (JIA), Psoriasis, and IBD ${ }^{2}$. Due to these activities, the frequency of use is increasing day by day. However, some unexpected and rare side effects not observed during clinical studies of these drugs have been observed in recent years. These side effects are called paradoxical because they occur after the initiation of anti-TNFs used in the treatment of diseases. These paradoxical conditions include new onset psoriasis or exacerbation of psoriasis, development of aseptic granulomatous disease such as sarcoidosis, uveitis and IBD ${ }^{5}$. However, it has been shown in publications that exacerbation of lesions during the use of TNF- $\alpha$ inhibitors in the treatment of psoriasis or publications have shown that psoriasis and psoriasiform eruptions may develop during the use of these agents for other indications. Reviews of anti-TNF-induced psoriasis in the literature; It includes infliximab, adalimumab and etanercept ${ }^{4}$. Skin lesions such as eczema, drug eruptions, drug-induced systemic lupus, dermatomyositis, lymphomatoid papulosis-like rash and psoriasis were reported in $10 \%$ of patients who received anti-TNF therapy. Paradoxical psoriasis has an annual incidence of 5\%, 5,6. Studies have shown that smoking is the main risk factor for the development of lesions ${ }^{5}$. In addition, combination therapy with anti-TNF and immunosuppressants is associated with a reduced risk of paradoxical psoriasis ${ }^{5}$.
According to the literature, the study involving two patients with RA in 2004 was the first study reporting the development of psoriatic skin lesions due to the use of infliximab and etanercept. Similar cases were published later. Two patients have been reported in Turkey, one of RA patient treated with infliximab and the other one is AS patient treated with etanercept ${ }^{7}$.

In a study conducted by Grinblat B and Scheinberg $\mathrm{M}$, they found 50 cases of psoriasis or psoriasiform skin lesions due to TNF- $\alpha$ inhibitor use between April 2005 and February 2007. The most common disease among these cases was determined as RA (56\%) followed by AS (22\%) and inflammatory bowel disease (14\%). Plaque psoriasis was reported as the most common skin lesion, followed by pustulous form. Other possible involvements have been reported as nail involvement and guttate psoriasis. It was determined that $66 \%$ of the patients used infliximab, 34\% used etanercept and $20 \%$ used adalimumab. In some cases, development of psoriasis has also been observed following the use of more than one type of TNF- $\alpha$ inhibitor.

Generally, symptoms developed after the initiation of Anti-TNF were seen as late side effects. However, the mean time for the onset of symptoms has not been established, as the time interval in cases varies significantly. Lesions resolved after discontinuation of therapy in all patients and remained stable while treatment continued ${ }^{6}$. Harrison MJ, Dixon WG, Watson KD, King Y, Groves R, and Hyrich KL conducted a study in RA patients who received anti-TNF therapy to identify those who developed psoriasis and identified 41 
cases. In these cases, psoriasis developed in the first nine months of treatment (average period of six months). In addition, it has been observed that in some cases, psoriasis occurs at different times from 7 days to 62 months. In the study, it was observed that adalimumab, the most recently used agent, causes psoriasis with the same frequency as infliximab and etanercept ${ }^{7}$. In the study, it was observed that adalimumab, the most recently used agent, causes psoriasis with the same frequency as infliximab and etanercept ${ }^{7}$. Although the causes of psoriasis following anti-TNF therapy have not yet been determined, several assumptions have been made. The first theory is that these patients are actually likely to have PsA, mistakenly diagnosed as RA or AS. In addition, it was stated that the development of cutaneous side effects may be caused by bacterial infections. On the other hand, it has been suggested that psoriasis may occur in association with other drugs used, and that some drug eruptions such as exanthematous pustulosis may mimic psoriasis ${ }^{7}$.

Psoriatic skin lesions seen as side effects have been associated with the use of TNF- $\alpha$ inhibitors. The development of lesions is due to TNF- $\alpha$ blockade, not to a specific TNF- $\alpha$ inhibitor. In some cases, observation of psoriatic lesions with multiple TNF- $\alpha$ inhibitors supports the class effect of TNF- $\alpha$ inhibitors as stated in the literature. In addition, the fact that two of the AS patients in the study were siblings suggests that genetic predisposition plays a role in the emergence of this side effect ${ }^{7}$. This side effect is noted to be associated with altered immunity that occurs in conjunction with inhibition of TNF activity in susceptible individuals. It is noted to be associated with altered immunity that occurs in relation to inhibition of TNF activity in susceptible individuals. Anti-TNF therapy has been shown to increase the activation of autoreactive $\mathrm{T}$ cells under certain conditions. Therefore, it is reported to cause tissue damage through autoimmune mechanisms. As with lupus-like syndromes or the development of anti-nuclear antibodies caused by anti-TNF, this may be due to a change in the inflammatory immune response. It has also been suggested that cytokine imbalance between TNF- $\alpha$ and interferon- $\alpha$ plays a key role in the development of psoriatic lesions in patients receiving chronic anti-TNF therapy. Other important cytokines such as IL (interleukin) -15, 17 and 12-23 have a role in the pathogenesis of psoriasis. Chronic anti-TNF therapy may affect the immunoregulatory pathways of these cytokines. Thus, it may cause the formation of psoriasis or psoriasiform lesions ${ }^{7}$. All these studies have shown that the mechanisms underlying the paradoxical phenomenon are still unknown. However, plasmacytoid dendritic cells (PDCs) and interferon- $\alpha$ (IFN- $\alpha$ ) appear to be key factors. TNF- $\alpha$ plays an important role in the regulation of IFN- $\alpha$ production as well as in the inhibition of hematopoietic PDC progenitor maturation. Inhibition of TNF- $\alpha$ may result in an abnormal IFN- $\alpha$ production by PDCs. There is clinical evidence that IFN- $\alpha$ suppresses TNF-a ', causing psoriasis disease activation ${ }^{6}$.

In the treatment of psoriatic lesions associated with the use of TNF- $\alpha$ inhibitors, it has been reported that the lesions improve with the discontinuation of the agents.

In some cases, the topical treatment initiated for psoriasis was sufficient without stopping the treatment, while in some cases the TNF- $\alpha$ inhibitor was changed and this paradoxical side effect could be treated by switching to a different agent.

As a result; In RA, AS and other inflammatory diseases, psoriasis may be induced or psoriatic skin lesions may occur or worsen in connection with the use of the TNF- $\alpha$ inhibitor. The most common form of psoriasis associated with anti-TNF therapy is the pustular form and plaque type with palmoplantar distribution.

\section{REFERENCES}

1.Esener S., Mevlitoğlu İ. "Pustular bakterid of Andrews during infiliximab therapy for ankylosing spondylitis: A case report". TURKDERM 48, sy S2 (15 Haziran 2014): 105-7. https://doi.org/10.4274/turkderm.48.s27

2. İpek S., Çekiç C., Alper E., Akpınar Z., Çamyar H, Kartal M., Ünsal B. "Ankilozan spondilit nedeniyle adalimumab kullanan bir hastada paradoksal olarak gelişen Crohn hastalığı”, Akademik Gastroenteroloji Dergisi. 2014. Cilt:12. Say1:3.

P118-121. https://doi.org/10.1794//agd.04622

3. Koyun B., Özalp E, Acet O, Erbaş O. "Romatolojik ve otoimmün hastalıklarda interlökin 23/tip 17 yardımc1 $T$ hücreleri yolağı için etkili güncel tedavi yöntemleri”. Demiroğlu Bilim Üniversitesi Florence Nightingale Transplantasyon Dergisi 3, sy 1 (2018): 025-030. https://doi.org/10.5606/fng.transplantasyon.2018. 007.

4. Böyük E., Bulur I., Saraçoğlu Z. N., Erdoğan H. K.,Arık D. "Romatoid Artrit Tanısı ile Golimumab Tedavisi Alan Hastada Gelişen Palmoplantar Püstülozis”. 
http://www.dermatoz.org/archives/archivedetail/article-preview/romatoid-artrit-tans-ilegolimumab-tedavisi-alan-h/36602 (06 Ekim 2020)

5. Pugliese D., Guidi 1., Ferraro P. M., Marzo M., Felice C., Celleno L., Landi R., vd. "Paradoxical Psoriasis in a Large Cohort of Patients with Inflammatory Bowel Disease Receiving Treatment with Anti-TNF Alpha: 5-Year Follow-up Study". Alimentary Pharmacology \& Therapeutics 42 , sy 7 (Ekim 2015): https://doi.org/10.1111/apt.13352.

880-88.

6. Lopes M. S. S., Trope M. B., Rodriguez M. P. R. R., Grynszpan R. L., Cuzzi T., Silva M. R.-e-.
"Paradoxical Reaction to Golimumab: Tumor Necrosis Factor $\alpha$ Inhibitor Inducing Psoriasis Pustulosa". Case Reports in Dermatology 5, sy 3 (2013):

326-31. https://doi.org/10.1159/000350930.

7. Sarpel T., Basaran S., Akcam F. D., Gunasti S., Denli Y. (2010). Psoriasis Induced by Tumor Necrosis Factor-Alpha Antagonist Therapy: Case Series and Literature Overview. Turkish Journal of Rheumatology, 25(2), 9194. doi:10.5152/tjr.2010.09 